\title{
Molecular characterization of Indian species of the genus Cornudiscoides Kulkarni, 1969 (Monogenoidea: Dactylogyridae)
}

\section{J. Verma}

Department of Zoology, University of Lucknow, Lucknow- 226007 (Uttar Pradesh), India

N. Agrawal*

Department of Zoology, University of Lucknow, Lucknow- 226007 (Uttar Pradesh), India

*Corresponding author. Email: dr_neeru_1954@yahoo.co.in

\section{Article Info}

https://doi.org/10.31018/

jans.v13i1.2434

Received: November 15, 2020

Revised: January 17, 2021

Accepted: January 24, 2021

\section{How to Cite}

Verma, J. and Agrawal, N. (2021). Molecular characterization of Indian species of the genus Cornudiscoides Kulkarni, 1969 (Monogenoidea: Dactylogyridae). Journal of Applied and Natural Science, 13(1), 1 - 7. https://doi.org/10.31018/jans.v13i1.2434

\section{Abstract}

Molecular characterization and phylogenetic study based on partial sequences of 28S and 18S ribosomal DNA (rDNA) of sixteen Indian species of the genus Cornudiscoides (Monogenoidea: Dactylogyridae) were conducted to decode the genetic relationship between them and with other members of the family Dactylogyridae. Blastn searches disclosed the significant similarity among the species of the Cornudiscoides for large ribosomal subunits as well as for small ribosomal subunit showing genetic relatedness. The phylogenetic tree using neighbour-joining ( $\mathrm{NJ}$ ) and minimum evolution (ME) methods for $28 \mathrm{~S}$ ribosomal subunit depicted that all Cornudiscoides species clustering in a single clade and forming sister clade with other members of the family Dactylogyridae and similar results were obtained from $18 \mathrm{~S}$ ribosomal subunit. Thus, the present study demonstrated that both $28 \mathrm{~S}$ and $18 \mathrm{~S}$ ribosomal subunits are very helpful in discriminating Cornudiscoides species (intra or interspecific variation) and in the establishment of the evolutionary relationship among them.
\end{abstract}

Keywords: Cornudiscoides, Dactylogyridae, Large and small ribosomal subunit, Maximum likelihood methods, Neighbour-joining, Phylogenetic analysis

\section{INTRODUCTION}

Systematics is a branch of science that described the world's biodiversity and its interrelationships (Van Steenberge et al., 2015). Traditionally, taxonomybased only morphological characters, but, given the constraints of morphology-based strategies in discriminating between cryptic species or decoding the variations of intraspecific variations, an integrative approach of taxonomy has been proposed (Dayrat et al., 2005). According to Schlick-Steiner et al. (2010) at least three impartial datasets: morphology, nuclear DNA and other supporting proof from another discipline should be used. Hard parts, i.e. haptor and male and female copulatory complex, are the main diagnostic features in monogenoideans taxonomy. Changes in the environmental conditions like locality and geographic distribution of host and age of parasites, the hard parts may exhibit variation in their structure (Agrawal et al., 2020). Thus, morphology is alone not sufficient in identifying species. Eukaryotic genes encoding ribosomal RNA (rRNA) is not only used as an effective taxonomic tool but recognized as a potential target for species identification, differentiation and phylogenetic analysis of helminths parasites. The $28 \mathrm{~S}$ and $18 \mathrm{~S}$ ribosomal DNA (rDNA) fragments particularly lend themselves to study as they provide sequences along with constant sites that permit multiple alignments among or between homologues, and variable sites that give phylogenetic information (Hillis and Dixon, 1991). In the recent era of molecular taxonomy, the ribosomal RNA (typical nucleic acid) frequently targeted for sequencing in eukaryotes and prokaryotes both (Olsen and Woese, 1993).

Kulkarni (1969) erected the genus Cornudiscoides at Hyderabad and established three species C. heterotylus Kulkarni, 1969 (type species), C. microtylus Kulkarni, 1969 and C. megalorchis Kulkarni, 1969 from Mystus tengara. To date, 16 species of the genus Cornudiscoides have been described and are distributed throughout South East Asia (Agrawal et al., 2016). Earlier reports showed that large ribosomal subunit 
(Mollaret et al., 1997 and 2000; Olson and Littlewood, 2002; and Verma et al., 2017) and small ribosomal (Matejusová et al., 2001, and Verma et al., 2017) useful to resolve relationships among monogenoidean parasites. In this study, twelve known species namely $C$. heterotylus Kulkarni, 1996; C. mystusi (Rizvi, 1971) Dubey et al., 1992; C. proximus Gusev, 1976; C. geminus Gusev, 1976; C. agarwali Agrawal and Vishwakarma, 1996; C. bleekerai Agrawal and Vishwakarma, 1996; C. gussevi Agrawal and Vishwakarma, 1996; C. susanai Agrawal and Vishwakarma, 1996; C. tukarami Agrawal and Vishwakarma, 1996; C. sclerovaginalis Devek and Pandey, 2007; C. longicirrus Agrawal et al., 2016; C. aori Agrawal et al., 2016 and four new species C. tripathii n. sp., C. speratai n. sp., C. indicus n. sp. and $C$. falcatum n. sp. were sequenced and partial sequences of the $28 \mathrm{~S}$ and $18 \mathrm{~s}$ ribosomal DNA were used to infer the relationships among the species of the genus Cornudiscoides and with the other members of the family Dactylogyridae.

\section{MATERIALS AND METHODS}

\section{Collection of parasites}

The hosts (commonly available freshwater food fishes for which ethical clearance is not required) were caught from River Gomati (Lucknow), Sai River (Lucknow), Manorama River (Basti), Betwa River (Jhansi), Amdhanpur Taal (Basti), Ramgarh Taal (Gorakhpur), and from the ponds of Mati (Barabanki) were examined Since January 2014 to January 2018. Collections were also made from the fish markets of Lucknow like Kaiserbagh, Daliganj, Dubbaga; Malihabad; Gonda, Sitapur, Hyderabad (Telangana) and Vizag (Andhra Pradesh). The live hosts were kept in plastic containers, aerated with battery operated aerators, brought to the laboratory, and maintained in glass aquaria. Fishes were identified with the help of Fish base (Froese and Pauly, 2014-2018), and Jayaram (1955). The gills of fishes were excised and were examined for the monogenoids. Living worms were studied under a phasecontrast microscope (Olympus CX41, Tokyo, Japan). The monogenoids were identified with the help of Pandey and Agrawal (2008). The gills infected with monogenoidean parasites were fixed in $3 \%$ formalin diluted with lukewarm water, temporary slides (glycerine mounts) and permanent slides ware prepared for morphometric study. The method for staining, mounting and illustration of parasites done according to Kristsky et al. (1986). For the molecular study, the gills were stored in $100 \%$ ethanol.

\section{Molecular analysis}

DNA (genomic) of the parasite (Cornudiscoides) was extracted from ethanol-preserved specimens using DNeasy Tissue Kit (Qiagen, Hilden, Germany) accord- ing to standard methods (Verma et al., 2018). A Partial region of $28 \mathrm{~S}$ and $18 \mathrm{~s}$ ribosomal DNA were amplified with the help of polymerase chain reaction (PCR) using the primers (Table 1) and reaction mixture prepared according to Verma et al., 2016 (Table 2). The thermal cycle started with $3 \mathrm{~min}$ at $94^{\circ} \mathrm{C}$ for initial denaturation; followed by 35 cycles of $30 \mathrm{~s}$ at $94^{\circ} \mathrm{C}, 30 \mathrm{~s}$ at $52^{\circ} \mathrm{C}$ for annealing, and $2 \mathrm{~min}$ at $72^{\circ} \mathrm{C}$ (extension); and a final extension at $72^{\circ} \mathrm{C}$ for $10 \mathrm{~min}$ followed by cooling at $4^{\circ}$ C. PCR products were examined on $1 \%$ agarose gel, stained with ethidium bromide and visualized on a gel documentation system. Sequencing was carried out according to Verma et al. (2017).

Blastn (Basic Local Alignment Search Tool) was performed for partial sequences of both $28 \mathrm{~S}$ and $18 \mathrm{~S}$ rDNA to uncover the degree of resemblance between species of the genus Cornudiscoides. ATGC calculator was used to evaluating the nucleotide composition among different species of the genus Cornudiscoides in this study. Sequences of the different species of the genus Cornudiscoides for $28 \mathrm{~S}$ and $18 \mathrm{~S}$ ribosomal subunit were amplified and sequenced and analysed with neighbour-joining and maximum likelihood methods. Sequences were reconstructed using Bioedit prior to analysis. Molecular evolutionary genetics analysis MEGA7 version 7.0 (Kumar et al., 2016), is software designed to infer phylogenetic relationship and pattern of evolution of nucleic acid and protein.

\section{RESULTS AND DISCUSSION}

\section{Molecular characterization}

The partial sequences of $28 S$ and 18S rDNA genes were used to assess the genetic differentiation of sixteen species of Cornudiscoides and their phylogenetic relationship among other groups of monogenoidean parasites. The large and small ribosomal subunits are extremely useful to explain the phylogeny of monogenoideans at the level of family and subfamily (Šimková et al., 2006) and the nucleotide sequences of monogenoideans have sufficient phylogenetic information to decode the relationship among them (Cunningham et al., 2000).

Sixteen newly generated sequences ranged from 327-1041 base pair long for large ribosomal subunit and 483-1109 base pair long for small ribosomal subunit (Table 4, 5), were obtained. All the sequences are submitted to the GenBank, National centre for biotechnology information (NCBI) and their accession numbers are given in Table 3 .

Blastn searches performed for $28 \mathrm{~S}$ region depicted that most of the members showed the highest similarity with C. agarwali (Table 4) while Blastn search for $18 \mathrm{~S}$ region, showed similarity with $C$. susanai (Table 5 ). The distribution of ATGC among different Cornudiscoides species deviated from species to species for both ribo- 
Verma, J. and Agrawal, N. / J. Appl. \& Nat. Sci. 13(1): 1 - 7 (2021)

Table 1. Primer pairs used for amplification of partial $28 S$ and $18 S$ ribosomal DNA and their sources.

\begin{tabular}{|c|c|c|c|}
\hline Gene & Primer & Primer sequence & Sources \\
\hline \multirow{2}{*}{$\begin{array}{l}28 \mathrm{~S} \\
\text { rDNA }\end{array}$} & Ancy55F (Forward) & GAGATTAGCCCATCACCGAAG (21 mer) & (Plaisance et al., 2005) \\
\hline & LSU1200R (Reverse) & GCATAGTTCACCATCTTTCGG (21 mer) & (Plaisance et al., 2005) \\
\hline \multirow{2}{*}{$\begin{array}{l}28 S \\
\text { rDNA }\end{array}$} & Universal primer (Forward ) & ACCCGCTGAATTAAGCAT ( 18 mer ) & (Shrivastava et al., 2013) \\
\hline & Universal primer (Reverse) & CTCTTCAGACTTTTCAAC (18 mer) & (Shrivastava et al., 2013) \\
\hline \multirow{2}{*}{$\begin{array}{l}18 \mathrm{~S} \\
\text { rDNA }\end{array}$} & Worm A (Forward) & ACGAATGGCTCATTAAATCAG (21 mer) & (Plaisance et al., 2005) \\
\hline & Worm B (Reverse) & CTTGTTACGACTTTTACTTCC (21 mer) & (Plaisance et al., 2005) \\
\hline
\end{tabular}

Table 2. Concentration of Master Mix for partial 28S and 18S rDNA amplification.

\begin{tabular}{lll}
\hline Component & Volume $(\boldsymbol{\mu l})$ & Final concentration \\
\hline PCR buffer $(10 \mathrm{x})$ & 3.0 & $1 \mathrm{x}$ \\
$\mathrm{MgCl}_{2}(50 \mathrm{mM})$ & 0.9 & $1.5 \mathrm{mM}$ \\
$\mathrm{dNTP}$ mixture $(10 \mathrm{mM})$ & 0.6 & $200 \mu \mathrm{M}$ \\
Primer forward $(10 \mu \mathrm{M})$ & 1.2 & $0.4 \mu \mathrm{M}$ \\
Primer reverse $(10 \mu \mathrm{M})$ & 1.2 & $0.4 \mu \mathrm{M}$ \\
Taq DNA polymerase $(5 \mathrm{U} / \mu \mathrm{l})$ & 0.4 & $2 \mathrm{U} / \mu \mathrm{l}$ \\
DNA & 6.0 & - \\
Milli Q water & 16.7 & - \\
Total volume & 30 & - \\
\hline
\end{tabular}

somal regions depicted in Table 4 and 5.

\section{Phylogenetic analysis}

Phylogenetic analysis was conducted among the members of the family Dactylogyridae for $28 \mathrm{~S}$ and $18 \mathrm{~S}$ ribosomal subunits. Newly obtained sequences along with twenty sequences belonging to different subfamilies members of the family Dactylogyridae, retrieved from GenBank, were used to evaluate their phylogenetic relationship. Evolutionary analyses were conducted in MEGA7 version 7.0 software (Kumar et al., 2016), using neighbour-Joining ( $\mathrm{NJ}$ ) and Minimum Evolution (ME) methods. Substitution, including transitions, transversions, gaps and missing data, were decimated. In the analyses, the codon positions (first, second and third) and non-coding sites were also included. The nodal values were estimated by bootstrapping $(n=1000)$. Phylogenetic analysis based on these two methods produced identical tree topologies with the branch length 0.10 and 0.05 for $28 S$ and $18 S$. The evolutionary distances were estimated with the help of the p-distance method.

However, the phylogenetic tree generated from both $28 S$ and 185 rDNA region depicted that the members of the family Dactylogyridae are separated on the basis of subfamilies i.e. members of subfamily Ancylodiscoidinae, Ancyrocephalinae, Pseudodactylogyrinae and Dactylogyrinae. They clustered separately, forming sister clades, with each other and separate clade with a member of Sundanonchidae for $28 \mathrm{~S}$ rDNA region (Fig.
1, 2). In the clade of Ancylodiscoidinae, all the species of Cornudiscoides clustered together and formed sister clade with Thaparocleidus spp. It is worth to note that, in the phylogenetic analysis of partial sequences of $28 S$ and $18 S$ ribosomal units, similar results were found, showing genetic relatedness among Cornudiscoides spp. while the separation of others reflects inter-specific/ intergeneric dissimilarities.

The species of the genus Cornudiscoides are chiefly differentiated by structure of their hard parts (haptor and genital armature) (Agrawal et al., 2020). The molecular study is conducted to complement morphometric analysis. Genetic distance portrays a degree of heterogeneity in the genetic constitution of taxa, therefore, becomes an ideal systematic tool (Fergusson, 2002). The ribosomal DNA of monogenoideans was used to evaluate phylogenetic relationship at the level of families and subfamilies (Plaisance et al., 2005; Šimková et al., 2003, 2006). In the identification of closely related parasites, PCR-based DNA sequencing technology provides an alternative approach (Nolan and Cribb 2005). Nucleotide sequences of monogenoideans have sufficient phylogenetic information to decode the relationship among them (Cunningham et al., 2000).

For the first time, the attempt has been taken for comprehensive analysis of sixteen species of Cornudiscoides, using 285 and $18 \mathrm{~S}$ rDNA partial sequences to show the genetic relatedness among them. Different sets of primers amplified different range of 327 to 1041 base pairs for $28 S$ region and 483 to 1109 base 
Verma, J. and Agrawal, N. / J. Appl. \& Nat. Sci. 13(1): 1 - 7 (2021)

Table 3. List of Monogenoideans and their accession numbers used into phylogenetic analysis.

\begin{tabular}{|c|c|c|c|}
\hline \multirow[t]{2}{*}{ S. No. } & \multirow[t]{2}{*}{ Cornudiscoides spp. } & \multicolumn{2}{|c|}{ GenBank Accession Number } \\
\hline & & $28 S$ & $18 S$ \\
\hline 1 & C. heterotylus & Submitted & MN187552 \\
\hline 2 & C. mystusi & KY091690 & KY091691 \\
\hline 3 & C. proximus & KU358726 & KU235550 \\
\hline 4 & C. geminus & $\begin{array}{l}\text { KU235549 } \\
\text { KU358727 }\end{array}$ & KU358728 \\
\hline 5 & C. agarwali & $\begin{array}{l}\text { KU208072 } \\
\text { KU208071 }\end{array}$ & KU928129 \\
\hline 6 & C. bleekerai & MK226180 & MN176410 \\
\hline 7 & C. susanai & MK226179 & MK396660 \\
\hline 8 & C. gussevi & - & MN219985 \\
\hline 9 & C. tukarami & MN176418 & MN176391 \\
\hline 10 & C. sclerovaginalis & MK403005 & - \\
\hline 11 & C. longicirrus & KY009858 & KY018927 \\
\hline 12 & C. aori & KY009859 & KY018928 \\
\hline 13 & C. tripathii n. sp. & MK282177 & MK402984 \\
\hline 14 & C. speratai n. sp. & MK575194 & MK570612 \\
\hline 15 & C. indicus n. sp. & MN179357 & - \\
\hline 16 & C. falcatum n. sp. & MK418453 & Submitted \\
\hline 17 & Thaparocleidus infundibulovagina & EF100548 & - \\
\hline 18 & Thaparocleidus indicus & JX960419 & - \\
\hline 19 & Thaparocleidus summagracilis & - & FJ493164 \\
\hline 20 & Thaparocleidus tacticus & - & FJ493161 \\
\hline 21 & Thaparocleidus durandi & - & FJ493162. \\
\hline 22 & Euryhaliotrematoides berenguelae & AY820615 & - \\
\hline 23 & Euryhaliotrematoides microphallus & AY820617 & - \\
\hline 24 & Euryhaliotrematoides annulocirrus & EU836195 & - \\
\hline 25 & Euryhaliotrematoides sp.1 & - & EU836217 \\
\hline 26 & Haliotrematoides spinatus & - & JN054404 \\
\hline 27 & Pseudodactylogyrus anguillae & AJ969950 & \\
\hline 28 & Pseudodactylogyrus sp. & EF100540 & \\
\hline 29 & Pseudodactylogyroides apogonis & - & AB065115 \\
\hline 30 & Pseudodactylogyrus haze & - & AB065114 \\
\hline 31 & Dactylogyrus anchoratus & JX524546 & - \\
\hline 32 & Dactylogyrus alatus & MG792957 & - \\
\hline 33 & Dactylogyrus falciformis & & FN391583 \\
\hline 34 & Dactylogyridae sp.4 & & EU836234 \\
\hline 35 & Sundanonchus micropeltis & AF218122 & - \\
\hline 36 & Sundanonchus behuri & GU830883 & - \\
\hline
\end{tabular}

pairs for $18 \mathrm{~S}$ region. The Blastn search disclosed the obscure relationship of these parasites with other species and showed the highest similarity with Cornudiscoides spp. for large as well as for small ribosomal subunit (Table 4 and 5).

The dispersion of ATGC bases (Table 4 and 5) for the two regions among Cornudiscoides spp. found deviated from species to species and exhibit clear-cut interspecific differences.

Among several sequences used in phylogenetic/ cladistic analysis, it was found that rDNA is extremely useful in evidencing intra and inter-specific variations among parasitic species since they evolve with varying rates from extremely conserved (18S, 5.8S and 28S) to extremely variable (transcribed and non-transcribed or IGS) regions (Hillis and Dixon 1991). Comparative study of $28 \mathrm{~S}$ and $18 \mathrm{~S}$ regions of ribosomal DNA reveals considerable sequence similarity as well as differences to define relativeness and phylogenetic relationship. These subunits have a wide range of phylogenetic utili- 


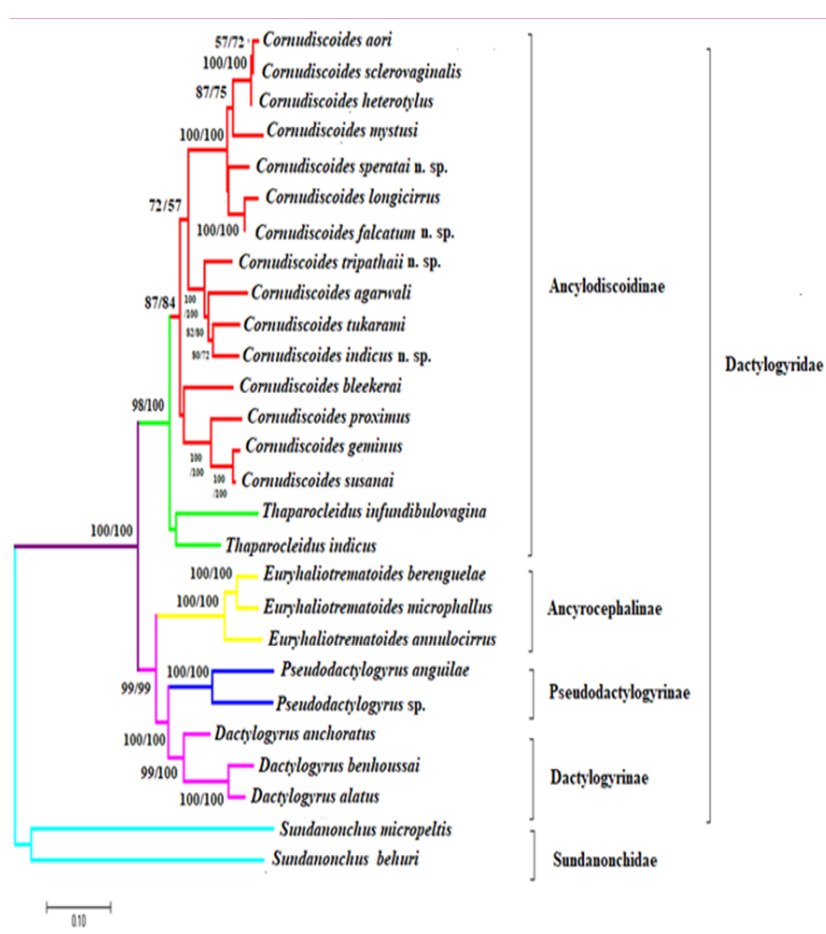

Fig.1.Tree topology for rDNA for members of the family Dactylogyridae for $28 \mathrm{~S}$ ribosomal subunit, using Neighbor-Joining (NJ) and Minimum Evolution (ME) methods. Bootstrap values support 1000 replicates below the nodes for $N J$ and above for ME.

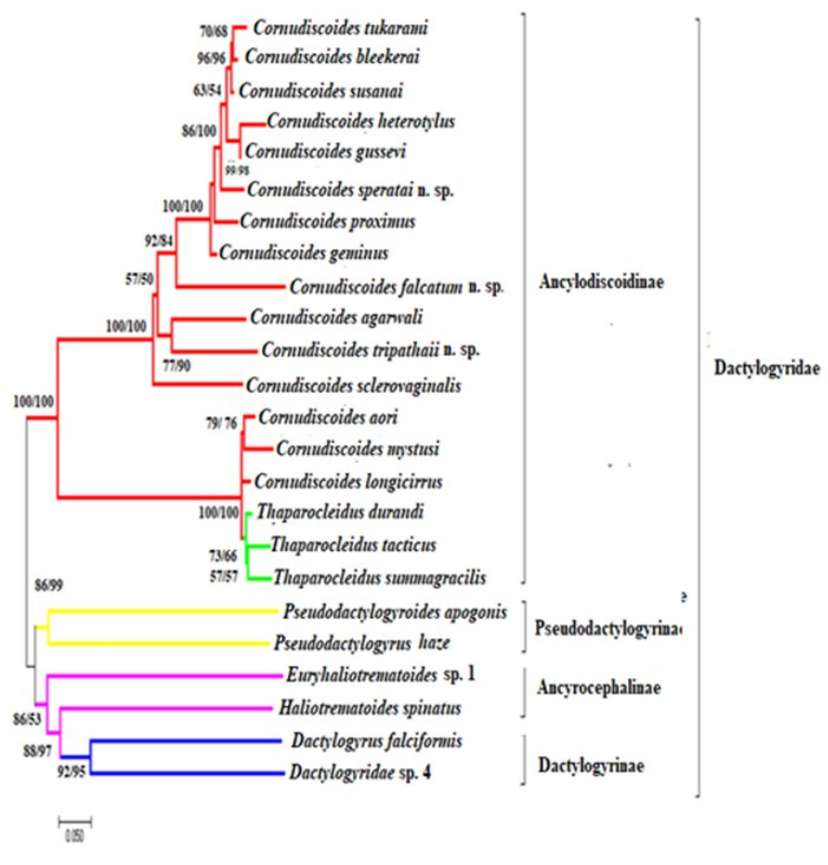

Fig. 2. Tree topology for rDNA for members of the family Dactylogyridae for18S ribosomal subunits, using Neighbor-Joining (NJ) and Minimum Evolution (ME) methods. Bootstrap values support 1000 replicates below the nodes for $\mathrm{NJ}$ and above for ME.

Table 4. Distribution of $A, T, G, C$ contents $\%$ of $G C$ and amplicon size along with blastn similarity of $28 \mathrm{~S}$ rDNA of Cornudiscoides species.

\begin{tabular}{|c|c|c|c|c|c|c|c|}
\hline $\begin{array}{l}\text { Cornudiscoides } \\
\text { spp. }\end{array}$ & $\begin{array}{l}\text { Adenine } \\
\text { (A) }\end{array}$ & $\begin{array}{l}\text { Thymine } \\
\text { (T) }\end{array}$ & $\begin{array}{l}\text { Guanine } \\
\text { (G) }\end{array}$ & $\begin{array}{l}\text { Cytosine } \\
\text { (C) }\end{array}$ & $\begin{array}{l}\text { GC } \\
(\%)\end{array}$ & $\begin{array}{l}\text { Amplicon } \\
\text { size (bp) }\end{array}$ & Blastn similarity \\
\hline C. heterotylus & 154 & 212 & 169 & 114 & 43.6 & 649 & $96.00 \%$ with C. susanai \\
\hline C. mystusi & 238 & 295 & 269 & 198 & 46.7 & 1000 & $92.24 \%$ with C. aori \\
\hline C. proximus & 220 & 274 & 236 & 156 & 44.2 & 886 & $95.30 \%$ with $C$ agarwali \\
\hline C. geminus & 216 & 266 & 238 & 153 & 44.8 & 873 & $97.41 \%$ with $C$. susanai \\
\hline C. agarwali & 255 & 295 & 257 & 182 & 44.4 & 989 & $97.78 \%$ with C. agarwali \\
\hline C. tukarami & 269 & 297 & 283 & 192 & 46.6 & 1041 & $95.34 \%$ with C. agarwali \\
\hline C. bleekerai & 89 & 76 & 93 & 69 & 49.5 & 327 & $96.59 \%$ with C. agawali \\
\hline C. susanai & 190 & 239 & 185 & 126 & 42 & 740 & $96.00 \%$ with C. agawali \\
\hline C. sclerovaginalis & 170 & 226 & 187 & 125 & 44.1 & 708 & $98.72 \%$ with C. aori \\
\hline C. longicirrus & 285 & 262 & 279 & 209 & 46.9 & 1030 & $92.23 \%$ with C. agarwali \\
\hline C. aori & 246 & 294 & 265 & 183 & 45.3 & 988 & $99.72 \%$ with C. sclerovaginals \\
\hline C. tripathii & 178 & 228 & 206 & 147 & 46.5 & 759 & $\begin{array}{l}98.05 \% \text { with } C . \text { geminus } \\
99.47 \% \text { with } C . \text { species LW }\end{array}$ \\
\hline C. speratai & 161 & 219 & 177 & 122 & 44 & 679 & $92.92 \%$ with C. longicirrus \\
\hline C. indicus & 252 & 283 & 260 & 182 & 45.2 & 977 & $92.25 \%$ with C. Proximus \\
\hline C. falcatum & 209 & 279 & 240 & 175 & 46 & 903 & $98.92 \%$ with C. longicirrus \\
\hline
\end{tabular}

ty (high sequence similarity with the highly variable region) providing an easy alignment between taxa (Littlewood et al., 1998) and are useful in genetic characterization of species.

In the computed phylogenetic tree for $28 \mathrm{~S}$ and $18 \mathrm{~S}$ regions, the species of Cornudiscoides, formed a different clade with other subfamily members of the family Dactylogyridae. All Cornudiscoides species clustered together in a single clade, forming sister clade with Thaparocleidus spp. showing a close relationship 
Verma, J. and Agrawal, N. / J. Appl. \& Nat. Sci. 13(1): 1 - 7 (2021)

Table 5. Distribution of A, T, G, C contents \% of GC and amplicon size of $18 \mathrm{~S}$ rDNA of Cornudiscoides species.

\begin{tabular}{|c|c|c|c|c|c|c|c|}
\hline $\begin{array}{l}\text { Cornudiscoides } \\
\text { spp. }\end{array}$ & $\begin{array}{l}\text { Adenine } \\
\text { (A) }\end{array}$ & $\begin{array}{l}\text { Thymine } \\
\text { (T) }\end{array}$ & $\begin{array}{l}\text { Guanine } \\
\text { (G) }\end{array}$ & $\begin{array}{l}\text { Cytosine } \\
\text { (C) }\end{array}$ & $\begin{array}{l}\text { GC } \\
\text { (\%) }\end{array}$ & $\begin{array}{l}\text { Amplicon } \\
\text { size (bp) }\end{array}$ & Blastn similarity \\
\hline C. heterotylus & 163 & 159 & 175 & 149 & 50.2 & 646 & $96.68 \%$ with C. susanai \\
\hline C. mystusi & 294 & 288 & 300 & 227 & 47.5 & 1109 & $98.24 \%$ with C. longicirrus \\
\hline C. proximus & 161 & 152 & 161 & 126 & 47.8 & 600 & $97.31 \%$ with C. susanai \\
\hline C. geminus & 132 & 122 & 125 & 104 & 47.4 & 483 & $98.17 \%$ with $C$ proximus \\
\hline C. agarwali & 148 & 140 & 159 & 148 & 51.6 & 595 & $99.44 \%$ with C. susanai \\
\hline C. tukarami & 152 & 172 & 180 & 134 & 49.2 & 638 & $98.65 \%$ with C. susanai \\
\hline C. gussevi & 142 & 129 & 144 & 144 & $48-8$ & 529 & $99.81 \%$ with C. susanai \\
\hline C. bleekerai & 181 & 204 & 211 & 164 & 49.3 & 760 & $98.79 \%$ with C. susanai \\
\hline C. susanai & 171 & 178 & 188 & 143 & 48 & 680 & $97.31 \%$ with C. proximus \\
\hline C. sclerovaginalis & 156 & 159 & 174 & 158 & 51.3 & 647 & $98.24 \%$ with C. mystusi \\
\hline C. longicirrus & 285 & 262 & 274 & 209 & 46.9 & 1030 & 98.24\% with C. mystusi \\
\hline C. aori & 246 & 233 & 253 & 196 & 48.4 & 928 & $97.14 \%$ with C. mystusi \\
\hline C. tripathii & 128 & 124 & 122 & 109 & 47.8 & 483 & $98.51 \%$ with C. geminus \\
\hline C. speratai & 197 & 217 & 211 & 164 & 47.5 & 789 & $94.86 \%$ with C. susanai \\
\hline C. falcatum & 252 & 246 & 230 & 215 & 47.2 & 943 & $78.62 \%$ with C. susanai \\
\hline
\end{tabular}

with each other and confirming the distinction from other Dactylogyrids. Thus, the tree topologies further confirm our preliminary results.

\section{Conclusion}

As in previous molecular studies conducted on monogenoidean parasites, results showed that the $18 \mathrm{~S}$ gene is a better potential marker than the $28 \mathrm{~S}$ gene (Blair and Barker, 1993; Cunningham et al., 1995; Zhu et al., 1998; Matejusová et al., 2001) but in the present study, we have found both the markers useful for the characterization of parasites. It is, therefore concluded that molecular markers strongly demonstrate the genetic delineation and confirms the validation of $C$. heterotylus, C. mystusi, C. proximus, C. geminus, C. agarwali, C. tukarami, C. bleekerai, C. susanai, C. gussevi, C. sclerovaginalis, C. longicirrus, C. aori, C. tripathii n. sp., C. indicus n. sp., C. speratai n. sp. and C. falcatum n. $\mathrm{sp}$. Thus, molecular study substantiated the morphological identity of different Cornudiscoides species and proves them genetically distinct species.

\section{ACKNOWLEDGEMENTS}

The present work was financially supported by University Grant Commission, India [F25-1/2013-14 (BSR)/7109/2007] to Jyoti Verma and [F.6-6/2017-18/Emeritus2017-18-Gen-9293/ (SA-II)] to Nirupama Agrawal.

\section{Conflict of interest}

The authors declare that they have no conflict of interest.

\section{REFERENCES}

1. Agrawal, N., Verma, J., Rajvanshi, S. \& Asthana, A. (2020). Application of two interesting statistical tools, used in differentiation of closely related species of Cornudiscoides Kulkarni, 1969 (Platyhelminthes: Monogenoidea: Dactylogyridae). Uttar Pradesh Journal of Zoology, 41(10), 143-156.

2. Agrawal, N., Rajvanshi, S. \& Verma, J. (2016). Two new species of the genus Cornudiscoides Kulkarni, 1969 from naked catfish Sperata aor (Hamilton, 1822): Specialist or Generalist? Pakistan Journal of Zoology, 48 (6) , 16871693.

3. Agrawal, N. \& Vishwakarma, P. (1996). Six new species and re-description of two known species of the genus Cornudiscoides Kulkarni, 1969 (Monogenea) from Lucknow U.P. Indian Journal of Helmintology, 13 (1-2), 10-31

4. Blair, D. \& Barker, S.C. (1993). Affinities of the Gyliauchenidae: utility of $18 \mathrm{~S}$ rRNA gene for phylogenetic inference in the Digenea (Platyhelminthes). International Journal for Parasitology, 23(4), 527-532. doi.org/10.10 16/0020-7519(93)90042-W

5. Cunningham, C.O., Aliesky, H. \& Collins, C.M. (2000). Sequence and secondary structure variation in the Gyrodactylus (Platyhelminth: Monogenea) ribosomal RNA gene array. Journal of Parasitology, 83 (3), 567576.doi.org/10.1645/0022-3395(2000) 086[0567:SASSVI] 2.0.CO;2

6. Cunningham, C.O., McGillivary, D.M. \& Mackenze, K. (1995). Phylogenetic analysis of Gyrodactylus salaries Malmberg, 1957 based on the small subunit (18S) ribosomal RNA gene. Molecular and Biochemical Parasitology, 71(1) 139-142. doi: 10.1016/0166-6851(95)00043-z

7. Dayrat, B. (2005). Towards integrative taxonomy. Biological Journal of Linnean Society, 85(3) , 407415. doi.org/10.1111/j.1095-8312.2005.00503.x

8. Devak, A. \& Pandey, K.C. (2007). A new species of 
Cornudiscoides Kulkarni, 1969 (Monogenoidea: Dactylogyridae) its locomotion, mode of attachment and distribution. Indian Journal of Helminthology, 25 (1-2), 41-58.

9. Dubey, A. Gupta, A.K. \& Agrawal, S.M. (1992). Studies on monogenean parasites in freshwater fishes at Raipur IX. Two new species of the genus Cornudiscoides Kulkarni,1969 and a taxonomic discussion on species included in it. Indian Journal of Helminthology, 44, 109-115.

10. Ferguson, J. W. H. (2002). On the use of genetic divergence for identifying species. Biological journal of the Linnean Society, 75(4), 509-516.

11. Froese, R. and Pauly, D. (2014-2018) Fish base. World Wide Web electronic publication. Version 10/2015. Available at www.fishbase.org (accessed).

12. Gusev, A.V. (1976). Freshwater Indian Monogenoidea. Principles of systematics, analysis of the world faunas and their evolution. Indian Journal of Helminthology, 25 and 26, 1-241.

13. Hillis, DM., \& Dixon, MT. (1991). Ribosomal DNA molecular evolution and phylogenetic inference. Quarterly Review of Biology, 66 (4), 411-453.doi: 10.1086/417338

14. Jayaram, K.C. (1955). Silurid fishes of India, Burma and Ceylon. XIV: Fishes of the genus Mystus Scopoli, 1777. Record Indian Museum (Culcutta), 51, 527-558.

15. Kritsky, DC., Thatcher, VE. \& Boeger, WA. (1986). Neotropical Monogenea 8. Reveision of Urocleidoides (Dactylogyridae, Ancyrocephalinae). Proceding of Helminthological Society of Washington, 53 (1) , 1-37.

16. Kulkarni, T. (1969). Studies on the monogenetic trematodes of fishes found in Hyderabad, Andhra Pradesh (India). Part I. Riv di Parasitologica 30 (2), 73-90.

17. Kumar, S., Stecher, G. \& Tamura, K. (2016). MEGA7: Molecular Evolutionary Genetics Analysis Version 7.0 for Bigger Datasets. Molecular Biology Evolution, 33(7) , 8701874. doi:10.1093/molbev/msw054. doi: $10.1093 / \mathrm{molbev} /$ msw054

18. Littlewood, D.T., Rohde, K. \& Clough, K.A. (1998). The phylogenetic position of Udonella (Platyhelminth). International Journal of Parasitology, 28 (8), 1241-1250. doi: 10.1016/s0020-7519(98)00108-8.

19. Matejusová, I., Koubková, B., Amelio, S.D. \& Cunniungham, C.O. (2001). Genetic characterization of six species of Diplozoon (Monogenea; Dioplozoiae). Parasitology, 123 (5), 465-474. doi: 10.1017/s0031182001008617.

20. Mollaret, I., Jamieson, B.G.M. \& Justine, J.L. (2000). Phylogeny of Monopisthocotylea and Polyopisthocotylea (Platyhelminthes) inferred from $28 \mathrm{~S}$ rDNA sequences. International Journal of Parasitology, 30 (2), 171-185. doi:10.1016/S0020-7519(99)00197-6.

21. Mollaret, I., Jamieson, B.G.M., Adlard, R.D., Hugall, A., Lecointre, G., Chombard, C. \& Justine, J.L. (1997). Phylogenetic analysis of the Monogenea and their relationships with Digenea and Eucestoda inferred from $28 S$ rDNA sequences. Molecular and Biochemical Parasitology, 90(2), 433-438. doi: 10.1016/S0166-6851(97)00176-X.

22. Nolan, M. \& Cribb, T. (2005). The use and implication of ribosomal DNA sequencing for the discrimination of dignean species. Advances in Parasitology, 60,101-163. doi: 10.1016/S0065-308X(05)60002-4

23. Olson, P. \& Littlewood D.T.G. (2002). Phylogeny of Mono- genea - evidence from a medley of molecules. International Journal for Parasitology, 32(3), 233-244. doi.org/10.1016/S0020-7519 (01)00328-9

24. Olsen, G.J. \& Woese, C.R. (1993). Ribosomal RNA: a key to phylogeny. FASEB $J$ 7, 113-123. doi:10.1096/fase bj.7.1.8422957

25. Pandey, K.C. \& Agrawal, N. (2008). An encyclopaedia of Indian Monogenoidea. New Delhi, Vitasta Publishing.

26. Plaisance, L., Littlewood, D.T.J., Olson, P.D. \& Morand, S. (2005). Molecular phylogeny of gill monogeneans (Platyhelminthes, Monogenea, Dactylogyridae) and colonization of Indo-West Pacific butterflyfish hosts (Perciformes, Chaetodontidae). Zoologica Scripta, 34 (4), 425-436. doi.org/10.1111/j.1463-6409.2005.00191.x.

27. Rizvi, S.S.H. (1971). Monogenea of Pakistan fishes I. Ancylodiscoides mystusi, New species and A. aori, New species, from the gills of Mystus aor (Ham.). Pakistan Journal of Zoology, 3, (2)87-92.

28. Schlick-Steiner, B.C., Steiner, FM. Seifert, B. Stauffer, C. Christian, E. \& Crozier, RH. (2010). Integrative taxonomy: a multisource approach to exploring biodiversity. Annual Review of Entomology, 55, 421-438. doi.org/10.1146/an nurev-ento-112408-085432.

29. Šimková, A., Matejusová, I. \& Cunniungham, C.O. (2006). A molecular phylogeny of the Dactylogyridae sensu Kristy and Boeger (1998) (Monogenea) based on the D1-D3 domain of larger subunit of rDNA. Parasitology, 133(1), 43-53. doi: 10.1017/S0031182006009942.

30. Šimková, A., Plaisance, L., Matejusová, I., Morand, S. \& Verneau, O. (2003). Phylogenetic relationships of the Dactylogyridae Bychowsky, 1933 (Monogenea: Dactylogyridea): the need for the systematic revision of the Ancyrocephalinae Bychowsky, 1937. Systematic Parasitology, 54(1), 1-11.doi.org/10.1023/A:1022133608662.

31. Shrivastava, R.R., Agrawal, N. \& Upadhyay, M.K. (2013). Molecular analysis based on 28S rDNA of Dactylogyroides species parasitizing Puntius species. Bioengineering and Biosciences, 1(3), 25-30. doi: 10.13189/bb.20 13.010301

32. Van Steenberge, M., Pariselle, A., Huyse, T., Volckaert, F. A., Snoeks, J., \& Vanhove, M. P. (2015). Morphology, molecules, and monogenean parasites: an example of an integrative approach to cichlid biodiversity. PloS one, 10, e0124474. doi.org/10.1371/journal.pone.0124474

33. Verma, J., Agrawal, N. \& Verma, A.K. (2016). The use of large and small subunits of ribosomal DNA in evaluating phylogenetic relationships between species of Cornudiscoides Kulkarni, 1969 (Monogenoidea: Dactylogyridae) from India. Journal of Helminthology, 91(2) , 206214. doi: $10.1017 /$ S0022149X16000134

34. Verma J., Rajvanshi S. \& Agrawal, N. (2018). Genetic characterization of three species of the genusCornudiscoides Kulkarni, 1969 (Monogenoidea: Dactylogyridae), Parasitizing long whiskered cat fish Sperata aor (Ham) using ribosomal and mitochondrial DNA. Journal of Zoological Sciences, 6, 31-37.

35. Zhu, X., Gasser, R.B. \& Chilton, N.B. (1998). Differences in the 5.8S rDNA sequences among ascarid nematodes. International Journal for Parasitology, 28(4), 617-622. doi.org/10.1016/S0020-7519(97)00214-2. 